species and nearly as many genera; together with some 58 asteroids and about 700 examples of an ophiuroid.

The general richness of the fauna provided a very marked contrast to the comparatively barren region round the Arabian coast and the azoic area of the Gulf of Oman. Until the collections have been worked out, it is impossible to give any details of the fauna of this African region, but the general impression created is that this region round Mombasa and Zanzibar has a fauna much more nearly allied with the fauna of the southern coast of the Gulf of Aden than with that of the northern coast of the Gulf.

\title{
Chemistry and Chemists in Spain
}

$\Delta \mathrm{T}$ the tenth meeting of the Union InterA nationale de Chimie held at Liege in 1930, apart from formal business, an adequate amount of time was devoted to consideration of problems connected with the constitution and properties of the simple and complex carbohydrates. Comprehensive papers previously circulated by recognised authorities prepared the way for useful discussions, and only in one or two cases was discussion rendered impossible by the tedious reading by authors of long manuscripts which either had been or should have been circulated previously. In spite of one or two drawbacks, the Liège meeting indicated how scientifically useful such international meetings may be when suitably organised.

When the invitation to hold the eleventh meeting of the Union in Madrid was accepted, it was decided by leading Spanish chemists to revive the pre-War International Congress of Chemistry at the same time, with the object of consolidating the scientific side of the meeting. The last meeting of the International Congress was held in Washington in 1912 and the meeting, postponed from 1932 to 1934, held in Madrid (April 5-11) constituted the Ninth International Congress. Some confusion may have arisen even among those attending that Congress and the eleventh meeting of the Union Internationale.

In spite of all the difficulties which have attended their work of organisation during the last two years, our Spanish colleagues have entertained their guests with lavish hospitality, both scientific and otherwise. The Congress and the meeting of the Union were opened in the ultra-modern Salle Capitol in the presence of the president of the Spanish Republic, who made what appeared to be an impressive speech in Spanish after the reading in Spanish by Prof. Fernandez of an account (previously circulated) of the developments in chemistry since the Eighth Congress. There were about 1,200 on the list of ordinary members of the Congress. This list included also the ladies who were kept busy enjoying the artistic and other treasures of Madrid, while the chemists were supposed to be busy discussing some of the 245 scientific communications, attending the four special lectures such as that of Prof. G. N. Lewis on "The Different Kinds of Water" and listening to the twenty special papers such as those given by Profs. P. Walden ("Anomale Elektrolyte in nichtwässerigen Lösungen"), G. Barger ("On the
Alkaloids of the Isochinolin Group"), R. Robinson ("Molecular Architecture of Plant Products"), R. H. Kruyt ("The Modern Development of Colloid Chemistry"), P. Karrer ("Untersuchungen über Carotinoide und Vitamine") and Miss Jordan Lloyd ("The Chemistry of the Tanning Process with Special Reference to Vegetable and Chrome Tanning"), the only lady chemist taking a leading part in the last two groups of special papers. Nearly all the communications to the Congress were circulated beforehand and intended to be the basis of discussion.

This huge scientific programme was interspersed with receptions by the president of the Republic at the National Palace and by the Mayor of Madrid at the Town Hall, visits to Toledo and Segovia and artistic entertainments terminating with a well-attended banquet. One heard also of several official or semi-official lunches and dinners and of private excursions before the dispersal of the delegates to the many places of interest in the south of Spain and even to Morocco. Everywhere, the members of the Congress were most kindly and graciously received and, apart from the somewhat adverse climatic conditions in Madrid, there was no sign anywhere of discomfort, alarm or even disquietude. The graciousness of our hosts was shown in a more permanent fashion by the conferring of honorary doctorates of the University of Madrid on seven delegates, among whom are Profs. H. E. Armstrong and R. Robinson, the election of ten foreign members of the Spanish Academy of Exact Sciences, among whom is Prof. G. Barger and, finally, the conferring of the new Order of the Spanish Republic on another eight delegates, among whom is Prof. E. Biilmann, president of the Union Internationale.

The permanent result of the Ninth International Congress is not easy to forecast. Many hope that its scientific proceedings will not be buried in a separate huge volume, but will find their way into more accessible journals devoted to the publication of contributions to chemical knowledge.

The meeting of the Union Internationale seemed to be overshadowed and was confined to two sittings of the Council and one of the Bureau, apart from those of several of the committees. In formal business, Prof. N. Parravano (Rome) was elected to succeed Prof. Biilmann in the presidency and the new members of the Bureau are Profs. M. Bodenstein (Berlin), E. Bartow (Iowa), F. Fichter (Basle), K. Matsubara ('Tokyo) 
and W. Swietosławski (Warsaw). The decision to accept the invitation to hold the twelfth meeting of the Union in Switzerland in 1936 was confirmed.

The chief subject of discussion by the Council concerned future arrangements for organisation concerning chemical nomenclature. The existence of separate committees for organic and biochemical nomenclature has for some years been regarded as unfortunate by many chemists in different countries, and the British Federal Council for Chemistry has been active in trying to have the two committees combined. The tone of the discussion was somewhat heated, and 'AngloSaxon' opposition to the existing committee on biochemical nomenclature was referred to in terms which created an atmosphere scarcely suitable for critical consideration of the best policy regarding a question of fundamental importance in chemistry.

The following proposals by Prof. F. Swartz were submitted : "In conformity with the decision of the Union the Committees on nomenclature are dissolved. The Council decides to constitute three new committees on nomenclature, one for inorganic chemistry, one for organic chemistry and one for biochemistry. These committees are asked to present a scheme of organisation of the future work of the committees on nomenclature to the Union before 31 December, 1935. Their presidents will assure the co-ordination of the work of these committees. The members of the committees will be chosen as far as possible from among the members of the former committees." These proposals were voted on according to countries adhering to the Union and passed by 29 to 28 votes. That there should be five members of each commission was again voted on in the same manner and passed by 31 to 27 votes. It was finally left to the Bureau to choose the members of the committee.

It may be questioned whether decisions of such a nature should be determined by countries having a number of votes based on their population and not by individual votes of representative chemists keenly interested in the matter ; but an important advance will be made if, by 1936 , the relative positions of organic chemistry and biochemistry on the question of nomenclature common to both are satisfactorily defined.

C. S. GiBson.

\section{Aberdeen Meeting of the British Association}

THE preliminary programme of the meeting 1 of the British Association to be held at Aberdeen on September 5-12 has now been issued. In certain respects a university city affords the best and most appropriate setting for a meeting of the Association, and Scottish meetings are anticipated with pleasure, for their standard of organisation has always been high, and they have always attracted a notable measure of public interest.

In Aberdeen, the accommodation for the sessions will be very convenient, for eight of the sections will be housed in Marischal College, and of the rest, four will find rooms within a quarter of a mile of the College. Only the Section of Botany will sacrifice nearness to the centre to the convenience of meeting in the appropriate department of the University, with its fine gardens, at St. Machar. The Reception Room will be in the Music Hall, a building of special historical interest to the Association, for it was opened in 1859, and the first ceremony which took place in it was the inaugural meeting of the Association in that year, when the Prince Consort occupied the chair. $\mathrm{He}$ conveyed a message from Queen Victoria to the Association, and delivered an address which is a pronouncement of no little interest in the history of science. His own sympathetic and wellinformed attitude toward science is well known, and is clearly defined in this address ; and no less clearly is indicated the general position of science in the life of the community at that time.

This point is apposite to the present programme, since particular contacts between science and the life of the community will be more prominent as subjects of discussion at Aberdeen than they are usually. Such topics are, of course, always to be found in Association programmes; but in recent years, and especially last year at Leicester, it has become clear that lay members and those who follow the proceedings of the meeting in the Press wish to hear more of them. It seems natural and proper that this should be so, and it is obviously within the stated objects of the Association that such a demand ought to be met. It is announced in the preliminary programme that "several Sections are including in their programmes papers or discussions within the scope of the resolution forwarded by General Committee to Council at the Leicester Meeting last year, on the relation between the advance of science and social progress" ; and a number of appropriate subjects are already announced. If from some of these there should emerge at Aberdeen applications for the appointment of committees to pursue investigations, this will mean that the Association's machinery is being used for the advancement of science in specific directions of public importance. There will be nothing new in this. The Association's record affords sufficient evidence for that statement. But the giving of "a more systematic direction" to scientific inquiry was one of the charges laid upon the Association by its founders ; and here, surely, is a systematic direction which has been rightly pointed out and will be rightly followed.

Sir James Jeans, who has succeeded the late Sir William Hardy as president of the Association, announces the title of his address as "The New World-Picture of Modern Physics". It is stated 